\title{
Predictive Factors of Response to Biological Disease Modifying Antirheumatic Drugs: Towards Personalized Medicine
}

\author{
Claire I. Daïen and Jacques Morel \\ Department of Rheumatology, Lapeyronie Hospital, University Montpellier I-II and IGMM-UMR5535, CNRS 1919, \\ Route de Mende, 34295 Montpellier Cedex 5, France \\ Correspondence should be addressed to Claire I. Daïen; cidaien@gmail.com
}

Received 2 October 2013; Accepted 27 November 2013; Published 12 January 2014

Academic Editor: Vera L. Petricevich

Copyright (c) 2014 C. I. Daïen and J. Morel. This is an open access article distributed under the Creative Commons Attribution License, which permits unrestricted use, distribution, and reproduction in any medium, provided the original work is properly cited.

\begin{abstract}
Many therapies are now available for patients with rheumatoid arthritis (RA) who have an inadequate response to methotrexate including tumor necrosis factor inhibitors, abatacept, tocilizumab, and rituximab. Clinical response to drugs varies widely between individuals. A part of this variability is due to the characteristics of the patient such as age, gender, concomitant therapies, body mass index, or smoking status. Clinical response also depends on disease characteristics including disease activity and severity and presence of autoantibodies. Genetic background, cytokine levels, and immune cell phenotypes could also influence biological therapy response. This review summarizes the impact of all those parameters on response to biological therapies.
\end{abstract}

\section{Introduction}

Many biological therapies are now available for patients with rheumatoid arthritis (RA) who have an inadequate response to synthetic disease modifying antirheumatic drugs (sDMARD) especially methotrexate (MTX) or to a first tumor necrosis factor (TNF) inhibitor (TNFi). They can be treated with either TNFi (etanercept (ETN), infliximab (IFX), adalimumab (ADA), certolizumab, or golimumab), or a T cell targeting therapy (CTLA4-Ig abatacept (ABA)) or an anti-IL6 receptor drug (tocilizumab (TCZ)), or a B cell targeting therapy, mostly represented by anti-CD20 antibodies like rituximab (RTX). Clinical response to drugs varies widely between individuals. A part of this variability is due to drug concentration and pharmacokinetic which is influenced by the characteristics of the patient such as age, gender, renal and liver functions, body mass index (BMI), or smoking status. Concomitant therapies and drug immunogenicity also influence drug concentrations. Clinical response depends on disease state and disease characteristics as well. Indeed, there are different subtypes of RA with different genetic backgrounds, that is, seropositive or seronegative RA [1] and benign or destructive RA [2-4]. Depending on patients, the
RA could be preferentially mediated by one cytokine; for example, some diseases are very dependent on TNF, whereas others are not [5]. One immune cell type can also be more important in some patients than others (i.e., B or T cells, Th1 or Th17 [6], etc.). Although all these parameters may influence therapeutic response, tools which could be used in daily practice to predict response to biological drugs are lacking. This review synthesizes the largest studies on factors influencing response to TNFi, ABA, RTX, and TCZ therapy (Table 1).

\section{Place of Patient's Characteristics in Predicting Response to Biological Therapies}

Several studies have assessed the value of age, gender, concomitant drugs, body mass index (BMI), or smoking status for predicting biological DMARD response. Most of them concerned TNFi.

\subsection{Age, Gender, and Concomitant Drugs}

2.1.1. TNFi. Several studies showed that male patients are more likely to respond to TNFi or to achieve remission with 
TABLE 1: Main studies presented in this review.

\begin{tabular}{|c|c|c|c|c|c|}
\hline References & $\begin{array}{l}\text { Study, cohort, or first } \\
\text { author name }\end{array}$ & Drugs studied & Study design & $\begin{array}{l}\text { Number of RA } \\
\text { patients }\end{array}$ & Endpoint \\
\hline$[6]$ & Chen & ADA, ETN & Cohort & 48 & $\begin{array}{l}\text { 6-month EULAR } \\
\text { response }\end{array}$ \\
\hline [7] & Kleinert & ADA & Noninterventional study & 2,625 & $\begin{array}{l}\text { 12-month DAS28 } \\
\text { variation }\end{array}$ \\
\hline$[8]$ & ReAct & $\mathrm{ADA}$ & Open-label study & 6,610 & $\begin{array}{l}\text { 12-week DAS28 } \\
\text { remission }\end{array}$ \\
\hline$[9]$ & TEMPO & ETN & $\begin{array}{l}\text { Randomized controlled } \\
\text { double-blind study (MTX } \\
\text { or ETN or MTX + ETN) }\end{array}$ & 682 & $\begin{array}{l}\text { 3-year DAS28 } \\
\text { remission }\end{array}$ \\
\hline$[10]$ & BSRBR & IFX and ETN & Prospective registry & 2,879 & $\begin{array}{l}\text { 6-month EULAR } \\
\text { response }\end{array}$ \\
\hline$[11]$ & GISEA & IFX, ADA, ETN & Retrospective registry & 1,565 & $\begin{array}{l}\text { 3-month EULAR } \\
\text { response }\end{array}$ \\
\hline$[12]$ & REACTION & TCZ & $\begin{array}{l}\text { Multicenter retrospective } \\
\text { study }\end{array}$ & 229 & $\begin{array}{l}\text { 24-week EULAR } \\
\text { response and DAS28 } \\
\text { remission }\end{array}$ \\
\hline [13] & DANBIO & TCZ & Prospective registry & 104 & $\begin{array}{l}\text { 24- and 48-week } \\
\text { EULAR response }\end{array}$ \\
\hline$[14]$ & ORA & TCZ & Prospective registry & 558 & $\begin{array}{l}\text { 6-month EULAR } \\
\text { response }\end{array}$ \\
\hline$[15]$ & BSRBR & RTX & Prospective registry & 540 & $\begin{array}{l}\text { 6-month EULAR } \\
\text { response and HAQ } \\
\text { improvement }\end{array}$ \\
\hline$[16]$ & Klaasen & IFX & Prospective cohort & 89 & $\begin{array}{l}\text { 16-week DAS28 } \\
\text { variation }\end{array}$ \\
\hline [17] & GISEA & IFX, ADA, ETN & Prospective registry & 641 & $\begin{array}{l}\text { 12-month DAS28 } \\
\text { remission }\end{array}$ \\
\hline$[19]$ & Abhishek & IFX, ADA, ETN & $\begin{array}{l}\text { Retrospective case control } \\
\text { study }\end{array}$ & 395 & $\begin{array}{l}\text { 3-month EULAR } \\
\text { response }\end{array}$ \\
\hline$[20]$ & Canhão & IFX, ADA, ETN & Prospective cohort & 615 & $\begin{array}{c}\text { EULAR response } \\
\text { maintained }>3 \\
\text { months in the 1st year }\end{array}$ \\
\hline$[21]$ & EIRA & IFX, ADA, ETN & Prospective cohort & 535 & $\begin{array}{l}\text { 3-month EULAR } \\
\text { response }\end{array}$ \\
\hline$[29]$ & Chatzidionysiou & RTX & Observational cohort & 2,019 & $\begin{array}{l}\text { 6-month EULAR } \\
\text { response }\end{array}$ \\
\hline$[31]$ & BSRBR & IFX, ADA, ETN & Prospective registry & 642 & $\begin{array}{c}\text { 6-month decrease of } \\
\text { DAS28 }\end{array}$ \\
\hline$[32]$ & Maneiro & TCZ, ABA, RTX & Meta-analysis & 23 studies pooled & $\begin{array}{l}\text { EULAR and ACR } \\
\text { responses }\end{array}$ \\
\hline [39] & Jamnitski & ETN & Cohort & 89 & $\begin{array}{l}\text { 28-week DAS28 } \\
\text { variations }\end{array}$ \\
\hline$[41]$ & Cui & IFX, ADA, ETN & Nine RA cohorts & 1,283 & EULAR response \\
\hline$[42]$ & Plant & IFX, ADA, ETN & Cohort & 1,115 & $\begin{array}{l}\text { 6-month EULAR } \\
\text { response }\end{array}$ \\
\hline$[43]$ & Plant & IFX, ADA, ETN & $\begin{array}{l}\text { Cohort from wellcome } \\
\text { trust case control } \\
\text { consortium }+2 \text { replication } \\
\text { cohorts }\end{array}$ & $566(+379$ and 341$)$ & $\begin{array}{l}\text { 6-month DAS28 } \\
\text { variations }\end{array}$ \\
\hline
\end{tabular}


TABLE 1: Continued.

\begin{tabular}{|c|c|c|c|c|c|}
\hline References & $\begin{array}{l}\text { Study, cohort, or first } \\
\text { author name }\end{array}$ & Drugs studied & Study design & $\begin{array}{c}\text { Number of RA } \\
\text { patients }\end{array}$ & Endpoint \\
\hline$[44]$ & SMART & RTX & Randomized open trial & 111 & $\begin{array}{l}\text { 24-week EULAR } \\
\text { response }\end{array}$ \\
\hline$[45]$ & Quartuccio & RTX & Cohort & 212 & $\begin{array}{l}\text { 4- and 6-month } \\
\text { EULAR response }\end{array}$ \\
\hline$[48]$ & Kayakabe & IFX, ADA, ETN & Prospective open study & 48 & $\begin{array}{l}\text { 24-week EULAR } \\
\text { response }\end{array}$ \\
\hline [49] & Wijbrandts & IFX & Cohort & 149 & $\begin{array}{l}\text { 16-week DAS28 } \\
\text { variations }\end{array}$ \\
\hline$[52]$ & RISING & IFX & $\begin{array}{l}\text { Double-blind randomized } \\
\text { trial }\end{array}$ & 327 & $\begin{array}{c}\text { 54-week DAS28 } \\
\text { variation and ACR } \\
\text { responses }\end{array}$ \\
\hline [53] & Hueber & ETN & Three different cohorts & $29+43+21$ & ACR responses \\
\hline$[54]$ & $\begin{array}{l}\text { RADIATE, OPTION, } \\
\text { TOWARD, } \\
\text { AMBITION and } \\
\text { LITHE }\end{array}$ & TCZ & Five phase 3 trials & 3,143 & $\begin{array}{l}\text { 16-week DAS28 } \\
\text { variations }\end{array}$ \\
\hline [57] & SMART & RTX & Randomized open label & 208 & $\begin{array}{l}\text { 24-week EULAR } \\
\text { response }\end{array}$ \\
\hline$[61]$ & Scarsi & $\mathrm{ABA}$ & Cohort & 32 & 6-month remission \\
\hline
\end{tabular}

ABA: abatacept; ADA: adalimumab; BSRBR: British society of rheumatology biologics register; DANBIO: nationwide registry of biological therapies in Denmark; DAS28: disease activity score 28 joints; EIRA: epidemiologic investigation of rheumatoid arthritis; ETN: etanercept; EULAR: european league against rheumatism; GISEA: Italian group for the study of early arthritis; HAQ: health assessment quality; IFX: infliximab; ORA: Orencia and Rheumatoid Arthritis; ReAct: research in active rheumatoid arthritis; SMART: a study of retreatment with MabThera (rituximab) in patients with rheumatoid arthritis who have failed on anti-TNF alfa therapy; TEMPO: Trial of Etanercept and Methotrexate with radiographic patient outcomes.

TNFi. Those studies include Kleinert's work that evaluated the effectiveness of ADA in 2,625 RA patients $(\beta 2$ weight $=$ -0.182, partial $r^{2}=0.003 ; P=0.003$ ) [7], the Research in Active RA trial (ReAct), a 12-week study open label on ADA that enrolled 6,610 RA patients $(\mathrm{HR}=1.284 ; 95 \% \mathrm{CI}=$ 1.160-1.422; $P=0.0001$ ) [8], and the Trial of Etanercept and Methotrexate with Radiographic Patient Outcomes (TEMPO) that included 682 patients receiving ETN $(\mathrm{OR}=$ $1.92 ; 95 \% \mathrm{CI}=1.32-2.77$ ) [9]. Younger patients were found to have better clinical outcomes in Kleinert's study $(\beta 2$ weight $=0.012$, partial $\left.r^{2}=0.014 ; P<0.001\right)$ [7] and in ReAct $(>75$ years versus $<40$ years: $\mathrm{HR}=0.611 ; 95 \% \mathrm{CI}=$ 0.461-0.810, $P=0.0006$ ) [8]. Conversely, no association with gender or age and clinical response was found in the British Society for Rheumatology Biologics Register (BSRBR) [10] and in the retrospective South Swedish Arthritis Treatment Group Register GISEA [11]. The use of MTX was associated with good clinical outcomes in many different studies including BSRBR [10], Kleinert's study [7], GISEA [11], and ReAct [8].

2.1.2. Other Biological Therapies. Concerning TCZ, the Japanese multicenter retrospective study (REACTION) involving 229 patients revealed that younger age was independently associated with a good EULAR response and remission at 24 weeks [12]. No other factors appeared to have a statistically significant predictive value for remission. In 104 RA patient included in DANBIO registry and treated with ABA, higher age was associated with EULAR good-ormoderate response $(\mathrm{OR}=1.04 /$ year increase $(95 \% \mathrm{CI} 1.01$ to $1.08 /$ year), $P=0.012$ ) [13]. Conversely, in the Orencia and Rheumatoid Arthritis (ORA), prospective registry which included 558 patients with RA, age, gender, and concomitant sDMARD did not significantly differentiate between EULAR responders and nonresponders [14]. In the 540 RTX-treated patients included in BSRBR who had experimented at least one TNFi failure, female sex was significantly associated with lower odds of disease remission $(0.45$ (95\% CI 0.12, 0.78)) [15].

2.2. Body Mass Index. The influence of BMI on therapeutic response at 16 weeks was evaluated in 89 RA patients treated with IFX $3 \mathrm{mg} / \mathrm{kg}$ [16]. BMI correlated positively with DAS28 at baseline. A negative association between BMI and the absolute decrease of DAS28 was found $(P=0.001)$. In GISEA, DAS28-remission at 12 months was noted in $15.2 \%$ of the obese subjects, in $30.4 \%$ of the patients with a BMI of $25-30 \mathrm{~kg} / \mathrm{m}^{2}$, and in $32.9 \%$ of the patients with a BMI of $<25 \mathrm{~kg} / \mathrm{m}^{2}(P=0.01)$ [17]. The difference in terms of remission percentage between obese patients and others was significant only in IFX-treated patients (not in ADA- and ETN-treated patients).

2.3. Smoking Status. There was a significant association between current cigarette smoking and a lower response in patients receiving IFX (OR 0.77 (95\% CI 0.60-0.99)) in the BSRBR [18]. This result was confirmed in a retrospective case control study of 395 RA [19], in a prospective cohort of 
TABLE 2: Main predictive factors of response to biological therapy.

\begin{tabular}{|c|c|c|c|c|}
\hline $\begin{array}{l}\text { Factors associated } \\
\text { with good response to }\end{array}$ & $\begin{array}{c}\text { Tumor necrosis factor } \\
\text { inhibitors }\end{array}$ & Tocilizumab & Abatacept & Rituximab \\
\hline $\begin{array}{l}\text { Patients } \\
\text { characteristics }\end{array}$ & $\begin{array}{c}\text { Male (C) }[7-9] \\
\text { Younger (C) }[7,8] \\
\text { Nonsmoker (C) }[10,19-21] \\
\text { Nonobese for IFX (C) } \\
{[16,17]} \\
\text { Use of MTX (C) }[7,8,10,11]\end{array}$ & Older (NC) [12] & Younger (NC) [13] & Male (NC) [15] \\
\hline $\begin{array}{l}\text { Disease } \\
\text { characteristics }\end{array}$ & $\begin{array}{c}\text { Low HAQ }(\mathrm{C})[7,10,17,20] \\
\text { High DAS28 (C) }[7,8,17] \\
\text { ACPA or RF negativity (C) } \\
{[20,31]} \\
\text { Low number of previous } \\
\text { biological therapies (C) }[8]\end{array}$ & $\begin{array}{c}\text { Low HAQ and high } \\
\text { DAS28 [13] }\end{array}$ & $\begin{array}{c}\text { High DAS28 [14] } \\
\text { RF positivity }(C)[32]\end{array}$ & $\begin{array}{l}\text { Low HAQ and high DAS28 } \\
{[15,32]} \\
\text { RF positivity }+++(\mathrm{C})[32] \\
\text { Low number of previous } \\
\text { biological therapies (C) } \\
{[29]}\end{array}$ \\
\hline Immunogenicity & $\begin{array}{l}\text { Antidrug antibodies against } \\
\text { ADA or IFX for response to } \\
\text { ETN (NC) [39] }\end{array}$ & & & \\
\hline Genetic background & $\begin{array}{c}\text { PTPRC }=\text { CD45 } \\
\text { (rs10919563) (C) [41, 42], } 7 \\
\text { SNPs including EYA4 } \\
(\text { rs17301249) and PDZD2 } \\
(\text { rs1532269) (NC) [43] }\end{array}$ & & & $\begin{array}{c}\text { 158VV FCGR3A in } \\
\text { European countries }(\mathrm{C}) \\
{[44,45]}\end{array}$ \\
\hline $\begin{array}{l}\text { Cytokines and } \\
\text { immune cells }\end{array}$ & $\begin{array}{c}\text { High TNF bioactivity in } \\
\text { blood [5] or in synovium } \\
\text { [49] (NC), high } \\
\text { LPS-stimulated whole } \\
\text { blood IL-1b (NC) [48], low } \\
\text { IL-17 (NC) [6] } \\
\text { 24-biomarker ETN } \\
\text { response signature } \\
\text { including autoantibodies } \\
\text { and cytokines (C) [53] }\end{array}$ & $\begin{array}{l}\text { High serum IL-6 levels } \\
\text { (NC) [54] }\end{array}$ & $\begin{array}{l}\text { Low levels of CD4+ and } \\
\text { CD8+ CD28- T cells } \\
\text { (NC) }[61]\end{array}$ & $\begin{array}{c}\text { Memory B cells (NC) } \\
{[57,58]}\end{array}$ \\
\hline
\end{tabular}

C: confirmed; NC: not confirmed. To be confirmed, the data had to be validated at least by two independent teams.

617 Portuguese [20] and in a Swedish register that included 1,998 early RA (Epidemiological Investigation of Rheumatoid Arthritis EIRA) [21]. However, it has not been demonstrated that smoking cessation increases the chance of response to therapies. In a Swedish study on 1,460 RA patients with disease duration $\leq 2$ years (BARFOT (better anti-rheumatic pharmacotherapy)), 127 patients quitted smoking after inclusion in the study. Smoking cessation was negatively associated with EULAR response at 8 years (OR $0.44(0.22-0.86) ; P=$ 0.02 ). To our knowledge, no data are currently available on the influence of smoking on response to TCZ, ABA, or RTX.

In summary, male gender, younger age, and nonsmoking status are better predictors of response or remission for patients starting a TNFi (Table 2). Concomitant use of MTX improves drug response. Obese patients are less likely to achieve remission with IFX. Only few data are available for TCZ, ABA, or RTX. The gender can influence the disease phenotype in RA. Male patients who have a later onset of RA are more likely to be seropositive for RF and have higher titers of anticitrullinated peptide antibodies compared with female patients $[22,23]$. They are also more likely to have a history of smoking and to carry the HLA-DRB1 shared epitope. Moreover, when comparing patients with a similar degree of radiographic joint destruction, women have worse scores for DAS28 and HAQ than men, possibly due to higher pain perception or an overestimate by men of their functional capacity [24]. Smoking is associated with a more severe disease and therefore probably more resistant to therapy [25, 26]. It also directly influences drug metabolism by inducing cytochrome P450 activity which was shown to impact other drug responses [27]. The concomitant use of MTX largely improves response through synergic actions of the drugs on RA but also probably by its impact on drug immunogenicity since the occurrence of antidrug antibodies is less frequent with MTX combined with biological therapies [28]. BMI influences drug concentration but is also associated with RA disease activity. Indeed DAS28 score increases with BMI in women $[16,22]$.

\section{Place of RA Characteristics in Predicting Response to Biological Therapies}

RA characteristics such as disease duration, disease activity score (DAS28), functional index (Health Assessment Quality (HAQ)), and previous therapeutics can influence drug 
response or presence of autoantibodies (rheumatoid factor (RF) and anticitrullinated peptide antibodies (ACPA)).

\subsection{DAS28, HAQ, and Previous Therapeutics}

3.1.1. TNFi. In most studies with TNFi, patients with higher baseline HAQ scores are less likely to respond or to achieve remission [8-10, 20]. In the British registry BSRBR, the Odd Ratio for EULAR response was 0.59 (95\% CI 0.50-0.69) per unit increase in HAQ. Moreover, high DAS28 at baseline is a good predictor of DAS28 decrease $[7,11]$ but is inversely associated with EULAR remission $[8,9,11]$. Multiple previous biologics are associated with a reduced therapeutic response $[7,8]$.

3.1.2. Other Biological Therapies. Similar finding were found for other therapies. In the 97 patients treated with TCZ registered in the nationwide Danish DANBIO registry, lower HAQ score at baseline was associated with EULAR response $(\mathrm{OR}=2.51$ (1.04-6.04), $P=0.041)$ [13] and higher DAS28 at baseline was significantly associated with achieving a low DAS28 (OR $=0.48(0.32-0.73), P<0.001)$ [13]. In ORA registry, initial DAS28 was higher in ABA responders (5.4 $(4.7-6.5))$ than in nonresponders $(4.9(4.0-6.0), P<0.0001)$ [14]. For RTX, several studies also showed association between EULAR response and low HAQ, high DAS28 and low number of previous biological agents $[15,29,30]$.

\subsection{Autoantibodies}

3.2.1. TNFi. Rheumatoid factor (RF) status was neither significantly associated with response to TNFi in BSRBR [10] nor with remission in ReAct and TEMPO studies [8, 9]. Presence of RF or ACPA was found to predict a reduced likelihood of treatment response [20,31]. Rheumatoid factor negative patients had a greater mean improvement in DAS28 (+0.48; 0.08-0.87) compared to RF positive patients at 6 months after adjusting for DAS28, HAQ, current DMARD therapy, and gender in BSRBR.

3.2.2. Other Biological Therapies. A meta-analysis of 23 clinical trials and observational studies showed that RF positivity at baseline predicts better ACR20 (OR, 1.95 (1.24, 3.08)), ACR50 (OR, $5.38(2.50,11.60)$ ), and EULAR response (OR, $3.52(1.66,7.45))$ in 14 studies with RTX and better ACR20 $(\mathrm{OR}, 1.51(1.21,1.90))$ in 6 studies with TCZ [32]. In 3 studies with ABA, no association was found between response and RF (OR $1.36(0.97,1.90))$.

In summary, higher DAS28 values at baseline are associated with response to biological therapies, which can be explained by a better chance of decreasing DAS28 of at least 0.6 if initial values are high. Conversely, patients with higher DAS28 values at baseline are less likely to achieve remission. High HAQ values and high numbers of previous biological therapies are associated with decreased chance of response which can be explained by more aggressive diseases. The presence of $\mathrm{RF} \pm \mathrm{ACPA}$ increases the chance of responding to RTX and to a lesser extent to ABA. Conversely, RF \pm ACPA positive status negatively influences the chance of TNFi response. Autoantibodies status could have impact on clinician choice. However strategy based on autoantibody positivity to introduce RTX rather than another biological drug still needs to be validated.

\section{Place of Drug Concentrations in Predicting Response to Biological Therapies}

Plasmatic concentrations of TNFi are known to influence therapeutic response. This was shown in patients treated with IFX [33], ADA [34], and ETN [35]. Previous studies found that the presence of neutralizing antidrug antibodies is associated with a reduction of drug levels below the therapeutic range and a suboptimal clinical outcome. Those antidrug antibodies are found in about $30 \%$ of the patients treated with monoclonal antibodies (IFX and ADA) and in a lower proportion $(0-5 \%)$ in patients treated with the soluble receptors (ETN) [35-37]. Drug concentration and antidrug antibody monitoring could also be used as a predictor of response to TNFi. We previously showed in 18 RA patients that 3-month ETN levels correlated significantly with change in DAS28 between baseline and 6 months $(r=-0.62$, $P=0.006$ ) [38]. Thus, measures of ETN concentration could help in the decision to continue or not the treatment in patients who have an insufficient response to treatment after 3 months. In a cohort of 292 RA patients treated with ETN, Jamnitski et al. compared the response of patients for whom ETN was the 1st TNFi and others. Eighty-nine out of 292 of these patients were switchers and had previously been treated with either IFX $(N=30)$ or adalimumab $(N=59)$. Among the switchers, 53\% of them had antidrug antibodies at baseline. TNFi naive patients responded better to ETN compared to switchers without antidrug antibodies after 16 weeks of etanercept treatment $(n=42)$ [39]. Conversely, DAS28 improvement in switchers with antidrug antibodies ( $n=47)$ did not differ from the one of TNFi naive patients. Thus in patients whose inadequate response to a first TNFi is not explained by antidrug antibodies, the disease seems to be mediated by other mechanisms than TNF and switching to another class of biologics, such as TCZ, ABA, or RTX, would be a better option.

\section{Place of Genetics in Predicting Response to Biological Therapies}

Many different single nucleotide polymorphisms (SNPs) were suggested to be associated with response to biological therapies, but very few have been confirmed. We voluntarily present here only data that have been replicated at least in another cohort.

5.1. TNFi. Using candidate gene approach, SNPs related to $\mathrm{TNF} \alpha$ or TNF $\alpha$ receptors (TNFR) were studied. In 2003, it was found that in 59 RA patients with TNFA-308G/G (rs1800629) responded better to IFX than those with A/A or $\mathrm{A} / \mathrm{G}$ genotypes (12847678) $(\mathrm{OR}=1.93 ; \mathrm{P}=0.009)$ [40]. Some other studies confirmed this data whereas others did not. A meta-analysis that included 11 studies and 2579 patients did not find a significant association between TNFA308 and TNFi response. Thirty-one SNPs associated with the 
risk of RA (i.e., TNFAIP3, STAT4, PTPN22, HLA class II, etc.) were analyzed in 1,283 RA patients [41]. The SNP at the CD45 (also called PTPRC) gene locus (rs10919563) was associated with EULAR good response versus no response $(\mathrm{OR}=0.55$, $P=0.0001)$ in multivariate analysis. This was confirmed in another large independent cohort of 1,115 English patients (OR $=0.62(0.40-0.95), P=0.03)$ [42].

In genome-wide association studies (GWAS) on 566 anti-TNF-treated RA patients, association with treatment response was found for 171 genotyped markers [43]. Seven of them were corroborate in the combined analysis of 2 independent replication cohorts $(n=379$ and $n=341)$. The strongest effect was at rs17301249, mapping to the EYA4 gene on chromosome 6: the minor allele conferred improved response to treatment (coefficient $-0.27, P=$ $\left.5.67 \cdot 10^{-5}\right)$. The minor allele of rs1532269, mapping to the PDZD2 gene, was associated with a reduced treatment response (coefficient $0.20, P=7.37 \cdot 10^{-4}$ ). The remaining associated SNPs mapped to intergenic regions on chromosomes 1 (rs12081765), 4 (rs4694890), 11 (rs1350948), and 12 (rs7305646 and rs7962316) [43].

5.2. Other Biological Therapies. 158V/F SNP of FCGR3A was shown to be associated with response to RTX in 111 patients included in an ancillary study of SMART [44]. V allele carriage independently associated with response to RTX (OR $3.8(1.2-11.7), P=0.023)$ in multivariate analysis. This was recently confirmed in a multicenter Italian study including 212 RA patients, with $89.5 \%$ of response at 6 months for $\mathrm{VV}$ versus $66 \%$ for $\mathrm{VF}$ and in $66.2 \%$ for FF patients $(P=$ 0.01 ) [45]. Probability of response at 6 months was very high when at least two of the three following items were present: positive rheumatoid factor and/or anticyclic citrullinated peptide antibodies, previous treatment with $\leq 1 \mathrm{TNFi}$, and 158VV FCGR3A genotype $(P<0.0001$; OR 7.9, 95\% CI 4.1 to 15.1). Similar results were found in non-Hodgkin lymphomas [46]. However, in an American study on 158 RA patients, FCGR3A 158V/F SNP was not associated with response to RTX [47].

In summary, CD45 (rs10919563), EYA4 (rs17301249), and PDZD2 (rs1532269) SNPs are associated in independent cohorts to TNFi response. The role of these different SNPs remained to be further studied. 158VV FCGR3A is associated with RTX response in European countries.

\section{Place of Cytokines and Immune Cell Assessment in Predicting Response to Biodrugs}

6.1. TNFi. One could speculate that a higher level of TNF$\alpha$ would be associated with a good response to TNFi. Kayakabe et al. measured by ELISA TNF- $\alpha$, IL- $1 \beta$, and IL- 6 in supernatant of LPS-stimulated whole blood cultures in $41 \mathrm{RA}$ patients before anti-TNF therapy [48]. This method evaluated monocytic cytokine production. IL- $1 \beta$ production at baseline was higher in 6-month responders (median IQR 10.0 (5.193.1) versus 3.5 (1.5-9.4) pg/mL for nonresponders). Another study using an in vitro bioassay, based on the induction of IL-6 and osteoprotegerin production by synoviocytes in response to TNF- $\alpha$, suggested that good responsiveness to TNFi was associated with significantly higher TNF- $\alpha$ bioactivity at baseline compared to nonresponding patients [5]. Moreover, TNF- $\alpha$ expression in the intimal lining layer and synovial sublining of 143 RA patients were significantly higher in responders than in nonresponders $(P=0.047$ and $P=0.008$, resp.) [49]. Those 3 studies support the idea that IL-1 and TNF- $\alpha$ activity influences response to TNFi, but these analyses cannot be performed in daily practice for technical reasons. Conversely, simple measures of circulating TNF could not predict response $[6,50,51]$.

Higher TNF- $\alpha$ production in an individual may also result in poorer response, simply due to a subtherapeutic drug dose. In RISING study, the baseline TNF $\alpha$ levels, measured by ELISA, predicted the necessity for dose escalation of IFX therapy in 327 patients with RA [52]. Patients with high baseline TNF had higher DAS28, higher levels of RF, and anti-CCP. Baseline TNF levels greatly affected serum IFX concentrations. In TNF-high patients, the median through serum levels of IFX was below limit of detection at 3 and $6 \mathrm{mg} / \mathrm{kg}$ and greater than $2 \mu \mathrm{g} / \mathrm{mL}$ at $10 \mathrm{mg} / \mathrm{kg}$, whereas the levels were approximately $1 \mu \mathrm{g} / \mathrm{mL}$ for each dosage in TNFlow patients. Patients with high TNF had a better clinical response to $10 \mathrm{mg} / \mathrm{kg}$ than to 3 or $6 \mathrm{mg} / \mathrm{kg}$. This difference was no significant difference in patients with low-TNF. Thus, $\mathrm{TNF} \alpha$ at baseline could predict the levels of TNF inhibition required.

In 48 RA patients treated with TNFi, IL-17 assessed by ELISA and Th17 at baseline was significantly higher in 6month EULAR nonresponders than in responders and was found to increase with TNFi in nonresponders, whereas it decreased in responders [6]. Multiple logistic regression analysis showed that high baseline IL-17 level $\geq 40 \mathrm{pg} / \mathrm{mL}$ could significantly predict poor response to TNFi $(P<0.01$; sensitivity $67 \%$ and specificity $83 \%$ ). Inadequate response to TNFi may reflect TNF-independent but Th17-dominant inflammatory process. This is a very interesting finding, but it has not been validated in another cohort yet.

With a multistep proteomics approach using arthritis antigen array, a multiplex cytokines assay and conventional ELISA, Hueber et al. identified a 24-biomarker signature that enables prediction of positive clinical response to ETN confirmed in three different cohorts (from USA $n=29$, Sweden $n=43$, and Japan $n=21$ ) with positive predictive values between 58 and $72 \%$ and negative predictive values from 63 to $78 \%$ (comparison of $\geq$ ACR50 and $<$ ACR20) [53]. These biomarkers included autoantibody profiles (i.e., fibromodulin (246-265), Clusterin (170-188), ApoE (277296) cit, etc.), and cytokines (including higher levels of GMCSF, IL-6, IL-1beta, and MCP-1 for responders). Combined autoantibody and cytokine profiles were more predictive for response to ETN in the three cohorts.

6.2. Other Biological Therapies. For TCZ, serum (3751 samples), genotype (927 samples), and transcript (217 samples) from five phase 3 trials of TCZ (RADIATE, OPTION, TOWARD, AMBITION, and LITHE) were analyzed to assess their association with treatment response [54]. Higher 


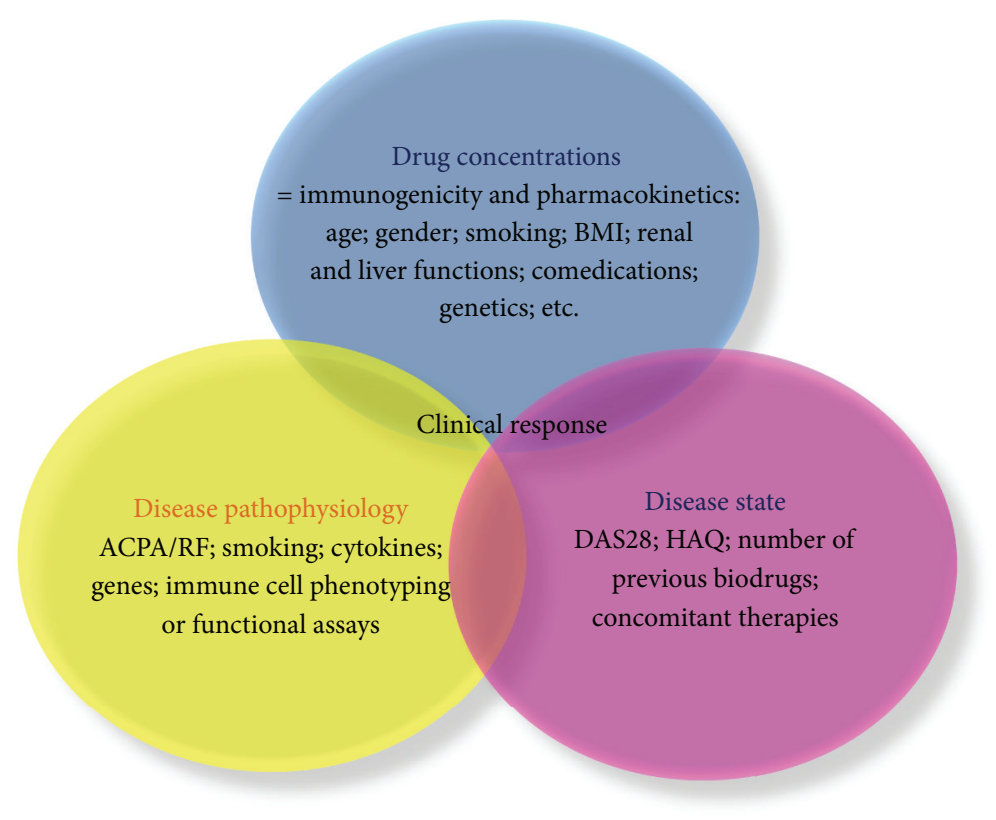

FIgURE 1: Clinical response depends on many different factors.

baseline serum IL-6 levels were significantly associated $(P<0.0001)$ with higher baseline DAS28, erythrocyte sedimentation rate, $\mathrm{C}$-reactive protein, and HAQ. Higher baseline serum IL-6 levels were also significantly associated with better clinical response to TCZ versus placebo in the pooled DMARD inadequate responders $(P<0.0001)$ and in MTXnaive populations $(P=0.04)$. However, the association with treatment response was weak with threefold difference in baseline IL-6 level corresponded to only a 0.17 -unit difference in DAS28 at week 16. This was also not true in TNFi inadequate responders, limiting the clinical usefulness of the marker in predicting treatment benefit. IL-6 pathway SNPs and RNA levels were also not strongly associated with treatment response.

Lymphocyte count and BAFF levels were suggested to predict response to RTX [55], but it has not been confirmed $[56,57]$. In SMART, low levels of CD27+ memory B cells were significantly associated with good response (OR 1.03 (1.011.05), $P=0.002$ ) although the association was too small to be used as a predictive biomarker in current practice. A similar trend was found in $103 \mathrm{RA}$ patients with higher levels of memory B cells in nonresponders (OR 0.67 (0.44-1.03), $P=$ 0.068) [58]. Conversely, Möller et al. found higher numbers of naive $\mathrm{B}$ cells in non- and moderate responders compared to good responders in 35 RA patients [59]. The numbers of memory B cells in the synovial tissue of 24 RA patients at baseline were not predictive of RTX response [60].

CTLA4 is similar to the T-cell costimulatory protein, CD28, and both molecules bind to CD80 and CD86 on antigen-presenting cells. CTLA4 transmits an inhibitory signal to T cells, whereas CD28 transmits a stimulatory signal. CD28 expression on the CD4+ and CD8+ T cells was studied in 32 patients with RA treated with ABA [61]. The overall predictive values of the CD8+CD28- and CD4+CD28- cells for DAS28-CRP remission at 6 months were 0.802 (SE 0.078) and 0.743 (SE 0.089), respectively. Cutoff values were proposed. For prediction of remission at 6 months, a concentration below 87 CD8+CD28- cells/ $\mu \mathrm{L}$ had $80.0 \%$ sensitivity and $81.8 \%$ specificity (Fisher's test: $P=0.001$ ), and a concentration below 28 CD $4+C D 28-$ cells $/ \mu \mathrm{L}$ had a $60.0 \%$ sensitivity and $77.3 \%$ specificity $(P=0.043)$. Patients having low baseline numbers of CD8+CD28- T cells had at least a 4-fold higher probability of achieving remission within 6 months compared to patients with higher levels of these cells. The same group observed that CD8+CD28- T cells decreased at 48 weeks of treatment with $\mathrm{ABA}$ and found that reductions of percentages of circulating CD4+CD28- and CD8+CD28$\mathrm{T}$ cells was directly correlated with the reduction of DAS28CRP ( $r=0.58, P=0.014 ; r=0.47, P=0.059$, resp.) [62].

In summary, sera concentrations of TNF $\alpha$ or IL-1 cannot be used to predict response to TNFi. Eventually, TNF levels could help to adapt IFX dosage. High IL-17 concentrations could be associated with nonresponse to TNFi, but it needs to be confirmed. Higher IL-6 concentrations are found in TCZ responders, but this measure cannot be used to predict response due to a too low predictive value. Immune cell phenotyping is not a good tool to discriminate responders from nonresponders except maybe for low levels of CD4+ and CD8+ CD28- T cells that could be associated with ABA response if it is confirmed.

\section{Conclusion}

Although many studies have identified predictive factors of response to biological therapies, only a few have been confirmed. Severe diseases (with high HAQ and numbers of previous biological drug failures) are more difficult to treat, whereas high DAS28 at baseline predicts stronger DAS28 
decrease regardless the type of treatment. For TNFi, male gender, younger age, nonsmokers, nonobese patients, ACPA or RF negative status predicts a good response to treatment and a few SNPs (PTPRC, EYA4, PDZD2, etc.) are also associated with good clinical outcomes. For TCZ, only IL6 levels were shown to be associated with response but in a weak manner. For ABA, RF positivity and low levels of CD4+ or CD8+ CD28- could help to predict response. For RTX, RF positivity is strongly associated with the response and can be used in clinical practice to guide clinician choice. Response to RTX also seems to be associated with FCGR3A SNP.

Despite some clinical and biological markers (Table 2), prediction of therapeutic response is a goal hard to achieve. The main difficulty is that response depends on at least three different parameters: drug concentrations, disease state, and disease pathophysiology; all of them are depending on many other different factors (Figure 1). Other predictive markers are still required. New approaches are being explored such as epigenetic studies or intracellular signaling response to cytokine stimulation on different immune cells. However, it is likely that no parameter will predict response if taken separately. Future studies should incorporate clinical and biological data to construct discriminating prediction scores that take into account the 3 axes of interindividual variability. Multicenter collaborations will be needed to include a significant number of patients. Finally, it is also important to appreciate the risk of adverse effect occurrence to choose for each patient the drug with the best risk benefit balance.

\section{Abbreviations}

ACPA: Anticitrullinated peptide antibodies

ACR: American college of rheumatology

ADA: Adalimumab

BAFF: B-cell activating factor

BMI: $\quad$ Body mass index

CRP: C-reactive protein

CTLA4: Cytotoxic T-lymphocyte antigen 4

DAS28: Disease activity score on 28 joints

BSRBR: British Society for Rheumatology Biologics Register

EIRA: Epidemiological Investigation of Rheumatoid Arthritis

ELISA: Enzyme-Linked Immunoabsorbent Assay

EULAR: European league against rheumatism

ETN: Etanercept

EYA4: $\quad$ Eyes absent homolog 4

FCGR3A: Fragment constant region receptor 3A

GM-CSF: Granulocyte macrophage colony-stimulating factor

GWAS: Genome-wide association studies

HAQ: Health Assessment Quality

HLA: Human leukocyte antigen

HR: Hazard ratio

IFX: Infliximab

IL: Interleukin

LPS: lipopolysaccharide

MCP-1: Monocyte chemoattractant protein 1

MTX: Methotrexate
OR: Odds ratio

ORA: Orencia and Rheumatoid Arthritis

PDZD2: PDZ domain containing protein 2

PTPN22: Protein tyrosine phosphatase, nonreceptor type 22

RA: Rheumatoid arthritis

ReAct: Research in Active RA trial

RNA: Ribonucleic acid

RF: $\quad$ Rheumatoid factor

RTX: Rituximab

sDMARD: Synthetic disease modifying antirheumatic drugs

SE: $\quad$ Standard error

SNPs: $\quad$ Single nucleotide polymorphisms

STAT4: Signal transducer and activator of transcription protein 4

TEMPO: Trial of Etanercept and Methotrexate with Radiographic Patient Outcomes

TCZ: Tocilizumab

Th: Thelper

TNF: Tumor necrosis factor

TNFAIP3: Tumor necrosis factor, alpha induced protein 3

TNFi: Tumor necrosis factor inhibitor.

\section{Conflict of Interests}

The authors declare that there is no conflict of interests regarding the publication of this paper.

\section{Acknowledgment}

The authors are thankful to Roche-Chugai (France) for supporting the open access.

\section{References}

[1] S. Viatte, D. Plant, J. Bowes et al., "Genetic markers of rheumatoid arthritis susceptibility in anti-citrullinated peptide antibody negative patients," Annals of the Rheumatic Diseases, vol. 71, no. 12, pp. 1984-1990, 2012.

[2] D. P. C. De Rooy, N. G. Yeremenko, A. G. Wilson et al., "Genetic studies on components of the Wnt signalling pathway and the severity of joint destruction in rheumatoid arthritis," Annals of the Rheumatic Diseases, vol. 72, no. 5, pp. 769-775, 2013.

[3] T. Suzuki, K. Ikari, K. Yano et al., "PADI4 and HLA-DRB1 are genetic risks for radiographic progression in RA patients, independent of ACPA status: results from the IORRA cohort study," PloS One, vol. 8, no. 4, Article ID e61045, 2013.

[4] M. P. M. Van Der Linden, A. L. Feitsma, S. Le Cessie et al., "Association of a single-nucleotide polymorphism in CD40 with the rate of joint destruction in rheumatoid arthritis," Arthritis \& Rheumatism, vol. 60, no. 8, pp. 2242-2247, 2009.

[5] H. Marotte, W. Maslinski, and P. Miossec, "Circulating tumour necrosis factor-alpha bioactivity in rheumatoid arthritis patients treated with infliximab: link to clinical response," Arthritis Research \& Therapy, vol. 7, no. 1, pp. R149-R155, 2005.

[6] D-Y. Chen, Y-M. Chen, H-H. Chen, C-W. Hsieh, C-C. Lin, and J-L. Lan, "Increasing levels of circulating Th17 cells and 
interleukin-17 in rheumatoid arthritis patients with an inadequate response to anti-TNF- $\alpha$ therapy," Arthritis Research \& Therapy, vol. 13, no. 4, article R126, 2011.

[7] S. Kleinert, H-P. Tony, A. Krause et al., "Impact of patient and disease characteristics on therapeutic success during adalimumab treatment of patients with rheumatoid arthritis: data from a German noninterventional observational study," Rheumatology International, vol. 32, no. 9, pp. 2759-2767, 2011.

[8] G. R. Burmester, G. Ferraccioli, R-M. Flipo et al., "Clinical remission and/or minimal disease activity in patients receiving adalimumab treatment in a multinational, open-label, twelveweek study," Arthritis Care \& Research, vol. 59, no. 1, pp. 32-41, 2008.

[9] D. Van Der Heijde, L. Klareskog, R. Landewé et al., "Disease remission and sustained halting of radiographic progression with combination etanercept and methotrexate in patients with rheumatoid arthritis," Arthritis \& Rheumatism, vol. 56, no. 12, pp. 3928-3939, 2007.

[10] K. L. Hyrich, D. P. M. Symmons, K. D. Watson, and A. J. Silman, "Comparison of the response to infliximab or etanercept monotherapy with the response to cotherapy with methotrexate or another disease-modifying antirheumatic drug in patients with rheumatoid arthritis: results from the British society for rheumatology biologics register," Arthritis \& Rheumatism, vol. 54, no. 6, pp. 1786-1794, 2006.

[11] L. E. Kristensen, M. C. Kapetanovic, A. Gülfe, M. Söderlin, T. Saxne, and P. Geborek, "Predictors of response to anti-TNF therapy according to ACR and EULAR criteria in patients with established RA: results from the South Swedish arthritis treatment group register," Rheumatology, vol. 47, no. 4, pp. 495499, 2008.

[12] H. Yamanaka, Y. Tanaka, E. Inoue et al., "Efficacy and tolerability of tocilizumab in rheumatoid arthritis patients seen in daily clinical practice in Japan: results from a retrospective study (REACTION study)," Modern Rheumatology, vol. 21, no. 2, pp. 122-133, 2011.

[13] H. C. Leffers, M. Østergaard, B. Glintborg et al., "Efficacy of abatacept and tocilizumab in patients with rheumatoid arthritis treated in clinical practice: results from the nationwide Danish DANBIO registry," Annals of the Rheumatic Diseases, vol. 70, no. 7, pp. 1216-1222, 2011.

[14] J. E. Gottenberg, P. Ravaud, A. Cantagrel et al., "Positivity for anti-cyclic citrullinated peptide is associated with a better response to abatacept: data from the "Orencia and Rheumatoid Arthritis" registry," Annals of the Rheumatic Diseases, vol. 71, no. 11, pp. 1815-1819, 2012.

[15] M. M. Soliman, K. L. Hyrich, M. Lunt, K. D. Watson, D. P. M. Symmons, and D. M. Ashcroft, "Effectiveness of rituximab in patients with rheumatoid arthritis: observational study from the British society for rheumatology biologics register," The Journal of Rheumatology, vol. 39, no. 2, pp. 240-246, 2012.

[16] R. Klaasen, C. A. Wijbrandts, D. M. Gerlag, and P. P. Tak, "Body mass index and clinical response to infliximab in rheumatoid arthritis," Arthritis \& Rheumatism, vol. 63, no. 2, pp. 359-364, 2011.

[17] E. Gremese, A. Carletto, M. Padovan et al., "Obesity and reduction of the response rate to anti-tumor necrosis factor? in rheumatoid arthritis: an approach to a personalized medicine," Arthritis Care \& Research, vol. 65, no. 1, pp. 94-100, 2013.

[18] K. L. Hyrich, K. D. Watson, A. J. Silman, D. P. M. Symmons, and British Society for Rheumatology Biologics Register, "Predictors of response to anti-TNF- $\alpha$ therapy among patients with rheumatoid arthritis: results from the British society for rheumatology biologics register," Rheumatology, vol. 45, no. 12, pp. 1558-1565, 2006.

[19] A. Abhishek, S. Butt, K. Gadsby, W. Zhang, and C. M. Deighton, "Anti-TNF- $\alpha$ agents are less effective for the treatment of rheumatoid arthritis in current smokers," Journal of Clinical Rheumatology, vol. 16, no. 1, pp. 15-18, 2010.

[20] H. Canhão, A. M. Rodrigues, A. F. Mourão et al., "Comparative effectiveness and predictors of response to tumour necrosis factor inhibitor therapies in rheumatoid arthritis," Rheumatology, vol. 51, no. 11, pp. 2020-2026, 2012.

[21] S. Saevarsdottir, S. Wedrén, M. Seddighzadeh et al., "Patients with early rheumatoid arthritis who smoke are less likely to respond to treatment with methotrexate and tumor necrosis factor inhibitors: observations from the epidemiological investigation of rheumatoid arthritis and the Swedish Rheumatology Register cohorts," Arthritis \& Rheumatism, vol. 63, no. 1, pp. 2636, 2011.

[22] D. Jawaheer, J. Olsen, M. Lahiff et al., "Gender, body mass index and rheumatoid arthritis disease activity: results from the QUEST-RA Study," Clinical and Experimental Rheumatology, vol. 28, no. 4, pp. 454-461, 2010.

[23] D. Jawaheer, R. F. Lum, P. K. Gregersen, and L. A. Criswell, "Influence of male sex on disease phenotype in familial rheumatoid arthritis," Arthritis \& Rheumatism, vol. 54, no. 10, pp. 30873094, 2006.

[24] M. Ahlmén, B. Svensson, K. Albertsson, K. Forslind, I. Hafström, and BARFOT Study Group, "Influence of gender on assessments of disease activity and function in early rheumatoid arthritis in relation to radiographic joint damage," Annals of the Rheumatic Diseases, vol. 69, no. 1, pp. 230-233, 2010.

[25] V. Ruiz-Esquide, J. A. Gómez-Puerta, J. D. Cañete et al., "Effects of smoking on disease activity and radiographic progression in early rheumatoid arthritis," The Journal of Rheumatology, vol. 38, no. 12, pp. 2536-2539, 2011.

[26] N. G. Papadopoulos, Y. Alamanos, P. V. Voulgari, E. K. Epagelis, N. Tsifetaki, and A. A. Drosos, "Does cigarette smoking influence disease expression, activity and severity in early rheumatoid arthritis patients?" Clinical and Experimental Rheumatology, vol. 23, no. 6, pp. 861-866, 2005.

[27] M. Ueno, J. L. Ferreiro, B. Desai et al., "Cigarette smoking is associated with a dose-response effect in clopidogrel-treated patients with diabetes mellitus and coronary artery disease: results of a pharmacodynamic study," JACC: Cardiovascular Interventions, vol. 5, no. 3, pp. 293-300, 2012.

[28] S. Garcês, J. Demengeot, and E. Benito-Garcia, “The immunogenicity of anti-TNF therapy in immune-mediated inflammatory diseases: a systematic review of the literature with a metaanalysis," Annals of the Rheumatic Diseases, vol. 72, no. 12, pp. 1947-1955, 2013.

[29] K. Chatzidionysiou, E. Lie, E. Nasonov et al., "Highest clinical effectiveness of rituximab in autoantibody-positive patients with rheumatoid arthritis and in those for whom no more than one previous TNF antagonist has failed: pooled data from 10 European registries," Annals of the Rheumatic Diseases, vol. 70, no. 9, pp. 1575-1580, 2011.

[30] L. Quartuccio, M. Fabris, S. Salvin et al., "Rheumatoid factor positivity rather than anti-CCP positivity, a lower disability and a lower number of anti-TNF agents failed are associated with response to rituximab in rheumatoid arthritis," Rheumatology, vol. 48, no. 12, pp. 1557-1559, 2009. 
[31] C. Potter, K. L. Hyrich, A. Tracey et al., "Association of rheumatoid factor and anti-cyclic citrullinated peptide positivity, but not carriage of shared epitope or PTPN22 susceptibility variants, with anti-tumour necrosis factor response in rheumatoid arthritis," Annals of the Rheumatic Diseases, vol. 68, no. 1, pp. 69-74, 2009.

[32] R. J. Maneiro, E. Salgado, L. Carmona, and J. J. Gomez-Reino, "Rheumatoid factor as predictor of response to abatacept, rituximab and tocilizumab in rheumatoid arthritis: systematic review and meta-analysis," Seminars in Arthritis and Rheumatism, vol. 43, no. 1, pp. 9-17, 2013.

[33] T. R. D. J. Radstake, M. Svenson, A. M. Eijsbouts et al., "Formation of antibodies against infliximab and adalimumab strongly correlates with functional drug levels and clinical responses in rheumatoid arthritis," Annals of the Rheumatic Diseases, vol. 68, no. 11, pp. 1739-1745, 2009.

[34] G. M. Bartelds, C. A. Wijbrandts, M. T. Nurmohamed et al., "Clinical response to adalimumab: relationship to antiadalimumab antibodies and serum adalimumab concentrations in rheumatoid arthritis," Annals of the Rheumatic Diseases, vol. 66, no. 7, pp. 921-926, 2007.

[35] A. Jamnitski, C. L. Krieckaert, M. T. Nurmohamed et al., "Patients non-responding to etanercept obtain lower etanercept concentrations compared with responding patients," Annals of the Rheumatic Diseases, vol. 71, no. 1, pp. 88-91, 2012.

[36] D. Pascual-Salcedo, C. Plasencia, S. Ramiro et al., "Influence of immunogenicity on the efficacy of long-term treatment with infliximab in rheumatoid arthritis," Rheumatology, vol. 50, no. 8, pp. 1445-1452, 2011.

[37] E. C. Keystone, M. H. Schiff, J. M. Kremer et al., "Once-weekly administration of $50 \mathrm{mg}$ etanercept in patients with active rheumatoid arthritis: results of a multicenter, randomized, double-blind, placebo-controlled trial," Arthritis \& Rheumatism, vol. 50, no. 2, pp. 353-363, 2004.

[38] C. I. Daïen, V. Daïen, E. Parussini, A.-M. Dupuy, B. Combe, and J. Morel, "Etanercept concentration in patients with rheumatoid arthritis and its potential influence on treatment decisions: a pilot study," The Journal of Rheumatology, vol. 39, no. 8, pp. 15331538, 2012.

[39] A. Jamnitski, G. M. Bartelds, M. T. Nurmohamed et al., "The presence or absence of antibodies to infliximab or adalimumab determines the outcome of switching to etanercept," Annals of the Rheumatic Diseases, vol. 70, no. 2, pp. 284-288, 2011.

[40] B. Mugnier, N. Balandraud, A. Darque, C. Roudier, J. Roudier, and D. Reviron, "Polymorphism at position -308 of the tumor necrosis factor $\alpha$ gene influences outcome of infliximab therapy in rheumatoid arthritis," Arthritis \& Rheumatism, vol. 48, no. 7, pp. 1849-1852, 2003.

[41] J. Cui, S. Saevarsdottir, B. Thomson et al., "Rheumatoid arthritis risk allele PTPRC is also associated with response to anti-tumor necrosis factor $\alpha$ therapy," Arthritis \& Rheumatism, vol. 62, no. 7, pp. 1849-1861, 2010.

[42] D. Plant, R. Prajapati, K. L. Hyrich et al., "Replication of association of the PTPRC gene with response to anti-tumor necrosis factor therapy in a large UK cohort," Arthritis \& Rheumatism, vol. 64, no. 3, pp. 665-670, 2012.

[43] D. Plant, J. Bowes, C. Potter et al., "Genome-wide association study of genetic predictors of anti-tumor necrosis factor treatment efficacy in rheumatoid arthritis identifies associations with polymorphisms at seven loci," Arthritis \& Rheumatism, vol. 63, no. 3, pp. 645-653, 2011.
[44] A. Ruyssen-Witrand, S. Rouanet, B. Combe et al., "Fc $\gamma$ receptor type IIIA polymorphism influences treatment outcomes in patients with rheumatoid arthritis treated with rituximab," Annals of the Rheumatic Diseases, vol. 71, no. 6, pp. 875-877, 2012.

[45] L. Quartuccio, M. Fabris, E. Pontarini et al., "The 158VV Fcgamma receptor 3A genotype is associated with response to rituximab in rheumatoid arthritis: results of an Italian multicentre study," Annals of the Rheumatic Diseases, 2013.

[46] G. Cartron, L. Dacheux, G. Salles et al., "Therapeutic activity of humanized anti-CD20 monoclonal antibody and polymorphism in IgG Fc receptor Fc $\gamma$ rIIIla gene," Blood, vol. 99, no. 3, pp. 754-758, 2002.

[47] K. Sarsour, J. Greenberg, J. A. Johnston et al., “The role of the FcGRIIIa polymorphism in modifying the association between treatment and outcome in patients with rheumatoid arthritis treated with rituximab versus TNF- $\alpha$ antagonist therapies," Clinical and Experimental Rheumatology, vol. 31, no. 2, pp. 189194, 2013.

[48] K. Kayakabe, T. Kuroiwa, N. Sakurai et al., "Interleukin-1 $\beta$ measurement in stimulated whole blood cultures is useful to predict response to anti-TNF therapies in rheumatoid arthritis," Rheumatology, vol. 51, no. 9, pp. 1639-1643, 2012.

[49] C. A. Wijbrandts, M. G. W. Dijkgraaf, M. C. Kraan et al., "The clinical response to infliximab in rheumatoid arthritis is in part dependent on pretreatment tumour necrosis factor $\alpha$ expression in the synovium," Annals of the Rheumatic Diseases, vol. 67, no. 8, pp. 1139-1144, 2008.

[50] S. M. Zivojinovic, N. N. Pejnovic, M. N. Sefik-Bukilica, L. V. Kovacevic, I. I. Soldatovic, and N. S. Damjanov, "Tumor necrosis factor blockade differentially affects innate inflammatory and Th17 cytokines in rheumatoid arthritis," The Journal of Rheumatology, vol. 39, no. 1, pp. 18-21, 2012.

[51] K. Shimamoto, T. Ito, Y. Ozaki et al., "Serum interleukin 6 before and after therapy with tocilizumab is a principal biomarker in patients with rheumatoid arthritis," The Journal of Rheumatology, vol. 40, no. 7, pp. 1074-1081, 2013.

[52] T. Takeuchi, N. Miyasaka, Y. Tatsuki et al., "Baseline tumour necrosis factor alpha levels predict the necessity for dose escalation of infliximab therapy in patients with rheumatoid arthritis," Annals of the Rheumatic Diseases, vol. 70, no. 7, pp. 1208-1215, 2011.

[53] W. Hueber, B. H. Tomooka, F. Batliwalla et al., "Blood autoantibody and cytokine profiles predict response to antitumor necrosis factor therapy in rheumatoid arthritis," Arthritis Research \& Therapy, vol. 11, no. 3, article R76, 2009.

[54] J. Wang, A. Platt, R. Upmanyu et al., "IL-6 pathway-driven investigation of response to IL-6 receptor inhibition in rheumatoid arthritis," BMJ Open, vol. 3, no. 8, Article ID 003199, 2013.

[55] G. Ferraccioli, B. Tolusso, F. Bobbio-Pallavicini et al., "Biomarkers of good EULAR response to the B cell depletion therapy in all seropositive rheumatoid arthritis patients: clues for the pathogenesis," PloS One, vol. 7, no. 7, Article ID e40362, 2012.

[56] J. Sellam, S. Rouanet, H. Hendel-Chavez et al., "Blood memory $\mathrm{B}$ cells are disturbed and predict the response to rituximab in patients with rheumatoid arthritis," Arthritis \& Rheumatism, vol. 63, no. 12, pp. 3692-3701, 2011.

[57] J. Sellam, H. Hendel-Chavez, S. Rouanet et al., "B cell activation biomarkers as predictive factors for the response to rituximab in rheumatoid arthritis a six-month, national, multicenter, openlabel study," Arthritis \& Rheumatism, vol. 63, no. 4, pp. 933-938, 2011. 
[58] E. M. Vital, S. Dass, A. C. Rawstron et al., "Management of nonresponse to rituximab in rheumatoid arthritis: predictors and outcome of re-treatment," Arthritis \& Rheumatism, vol. 62, no. 5, pp. 1273-1279, 2010.

[59] B. Möller, D. Aeberli, S. Eggli et al., "Class-switched B cells display response to therapeutic B-cell depletion in rheumatoid arthritis," Arthritis Research \& Therapy, vol. 11, no. 3, article R62, 2009.

[60] R. M. Thurlings, K. Vos, C. A. Wijbrandts, A. H. Zwinderman, D. M. Gerlag, and P. P. Tak, "Synovial tissue response to rituximab: mechanism of action and identification of biomarkers of response," Annals of the Rheumatic Diseases, vol. 67, no. 7, pp. 917-925, 2008.

[61] M. Scarsi, T. Ziglioli, and P. Airo, "Baseline numbers of circulating CD28-negative T cells may predict clinical response to abatacept in patients with rheumatoid arthritis," The Journal of Rheumatology, vol. 38, no. 10, pp. 2105-2111, 2011.

[62] M. Scarsi, T. Ziglioli, and P. Airo, "Decreased circulating CD28negative $\mathrm{T}$ cells in patients with rheumatoid arthritis treated with abatacept are correlated with clinical response," The Journal of Rheumatology, vol. 37, no. 5, pp. 911-916, 2010. 


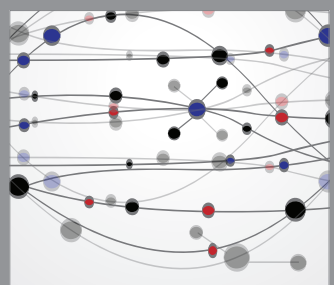

The Scientific World Journal
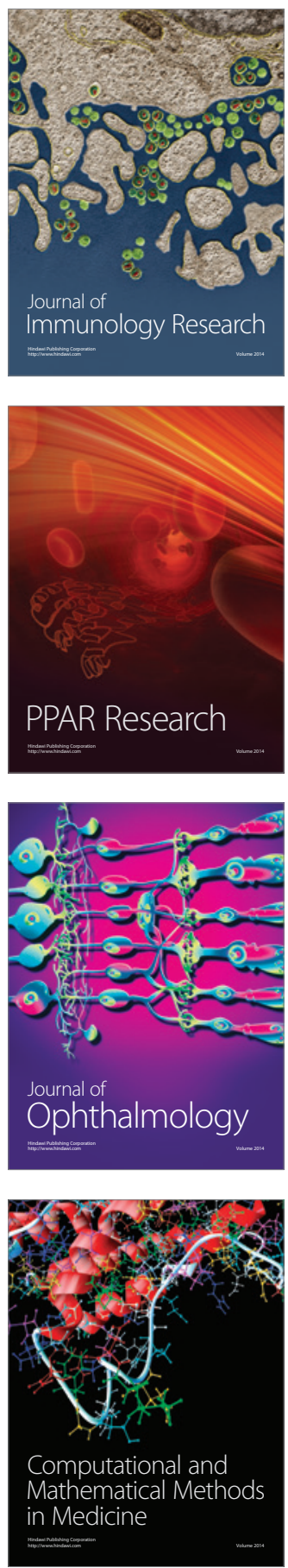

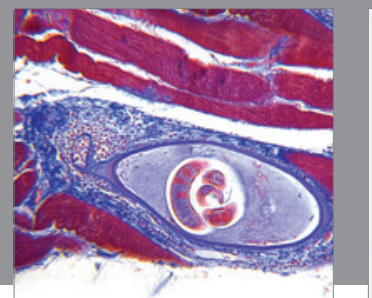

Gastroenterology

Research and Practice
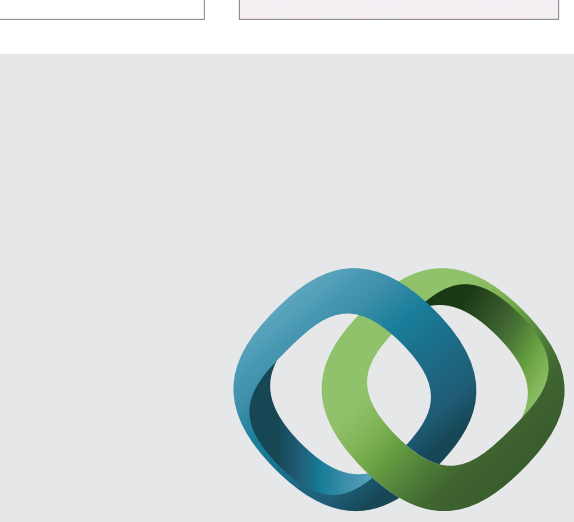

\section{Hindawi}

Submit your manuscripts at

http://www.hindawi.com
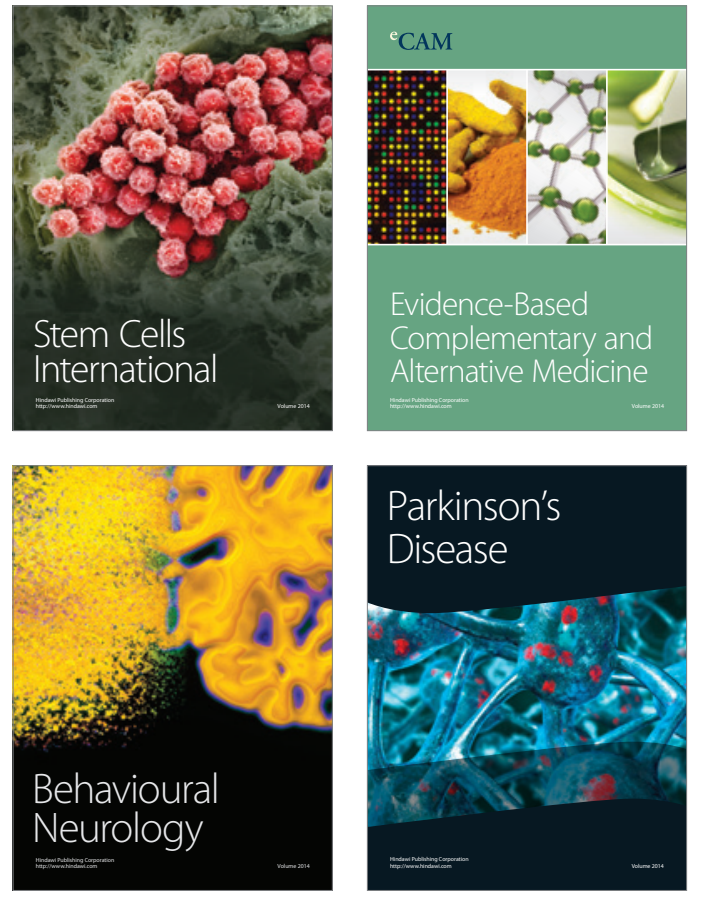
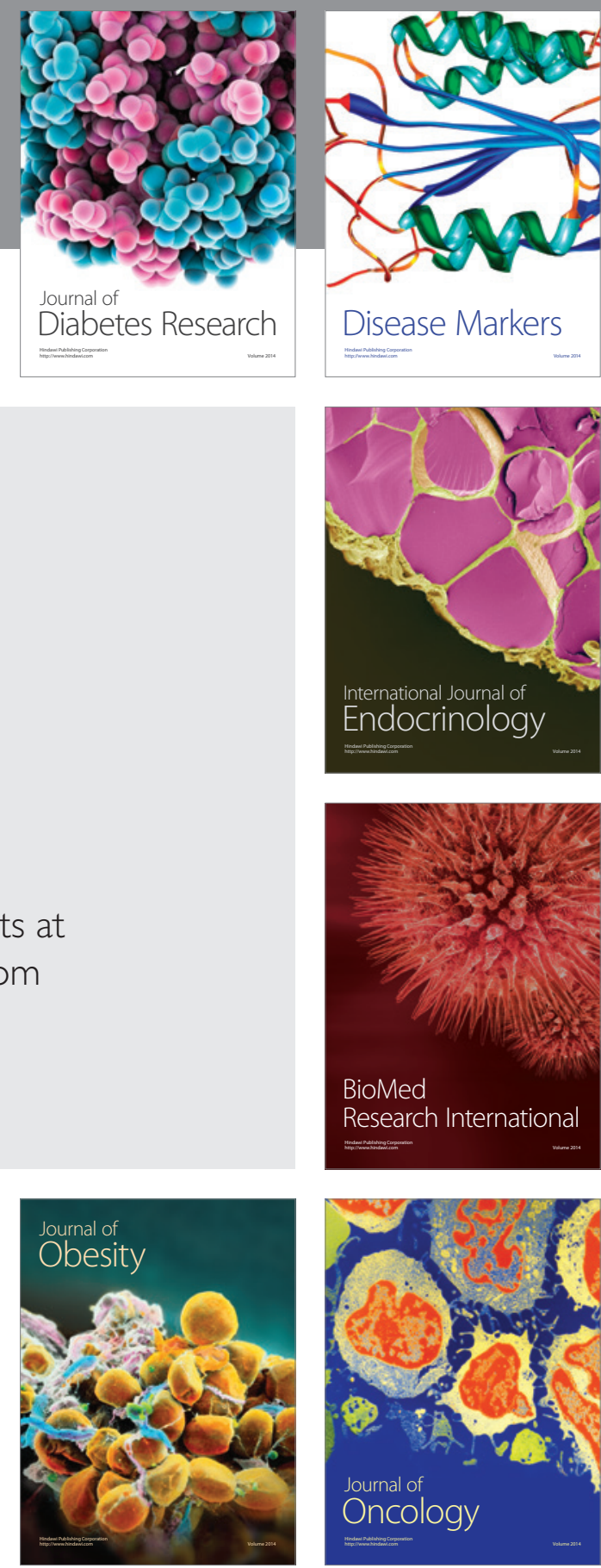

Disease Markers
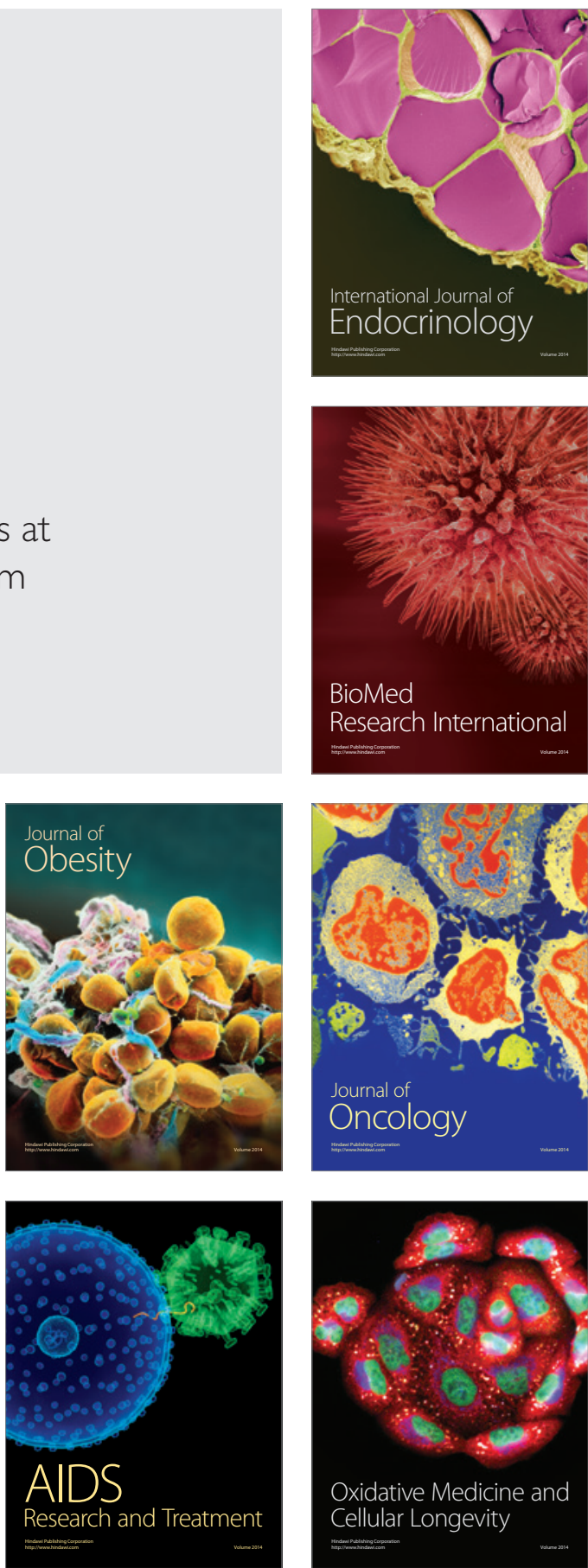